TAO, Vol. 14, No. 1, 63-83, March 2003

\title{
Velocity Structure, Seismicity, and Fault Structure in the Peikang High Area of Western Taiwan
}

Win-Bin Cheng ${ }^{1, *}$, Hui-Chen Huang ${ }^{2}$, Chengsung Wang ${ }^{2}$, Ming-Shyan Wu $^{3}$, and Ta-Heng Hsiuan ${ }^{3}$

(Manuscript received 22 April 2002, in final form 10 February 2003)

\begin{abstract}
As an attempt to investigate the sub-surface geometry of the Peikang High, and the structural features that may have influenced the regional seismicity of western Taiwan, a three-dimensional (3-D) P-wave velocity model has been developed. The velocity model was determined by simultaneously inverting of $\mathbf{P}$ - and $\mathrm{S}$-wave arrival times recorded by the Central Weather Bureau Seismographic Network for earthquakes occurred from 1991 to 2000. In order to have a good constrain for the shallow part of the velocity model, the results of geophysical survey and drilling data of the Peikang High region conducted by the Chinese Petroleum Corporation are used in the initial 3-D model. Based on the results of restoring resolution and checkerboard test, the upper and middle crust is well resolved throughout the onshore and southern part of offshore in the study area. In general, the velocity transition zone from low to high is located beneath the Western Foothills region. The prominent feature of the velocity model is that the uplift high velocity volume exist in the middle- and lower-crust beneath the areas west to the Western Foothills should be associated with the Peikang High. The Peikang High is overlaid with the Coastal Plain, a basin type containing low velocity materials. The geometry of the Peikang High materials seems to affect the distribution of surficial faults and topography. In addition, most of the relocated Chi-Chi hypocenters are in the low velocity zones of the study area.
\end{abstract}

(Key words: Peikang high, Seismic tomography, Chi-Chi earthquake)

\section{INTRODUCTION}

The whole Taiwan region is tectonically active resulting from the late Cenozoic oblique

\footnotetext{
${ }^{1}$ General Education Center, Jin-Wen Institute of Technology, Taipei, Taiwan, ROC

${ }^{2}$ Institute of Applied Geophysics, National Taiwan Ocean University, Taipei, Taiwan, ROC

${ }^{3}$ Chinese Petroleum Corporation, Taipei, Taiwan, ROC

* Corresponding auther address. Dr. Win-Bin Cheng, General Education Center, Jin-Wen Institute of Technology, No. 99 An-Chung Rd., Hsin-Tien, Taipei, Taiwan, ROC; E-mail: wbin@jwit.edu.tw
} 
convergence between the Philippine Sea plate and the Eurasian plate (Fig. 1), as indicated by its very high seismicity (e.g., Tsai 1986; Wang and Shin 1998), regional-scale crustal faulting (e.g., Barrier and Angelier 1986; Lallemand et al. 2001) and rapid crustal movement (Yu et al. 1997). It is clear that the tectonic features of the Taiwan Island are responses to the stress imposed by the convergence of the Philippine Sea plate. In terms of tectonics, it is believed that the northwestward movement of the crustal materials has been impeded by the Peikang High (Fig. 1; e.g., Hu et al. 1997; Wang et al. 2000). Meng (1971) proposed that the Peikang High played the role of a tectonic barrier or dam during the Miocene. The velocity field obtained from GPS surveys since 1991 (Yu et al. 1997), showed significant deformation in the Western Foothills and the Central Range, while only small crustal deformation was observed in the Peikang High (Fig. 1). From the background seismicity and aftershock distribution of the 1999 Chi-Chi earthquake (e.g., Wang et al. 2000; Lin 2001), a low-seismicity region is roughly consistent with the semi-circular Peikang High. Thus, the Peikang High deserves particular consideration because of its tectonic role in Taiwan during continent collision and its seismogenic behavior in western Taiwan. Although previous studies indicated that the Peikang High is a major basement high in front of the fold-and-thrust belt, it is also a gravity and a magnetic high (e.g., Hseih and Hu 1972; Sun 1985). Yet not much is known about its sub-surficial geometry and velocity nature, and deserves a detailed investigation.

As mentioned above, the Peikang High represents a low-seismicity region comparing to the surrounding areas. Even during the 1999 Chi-Chi earthquake, which was the most damaging earthquake have stricken the central Taiwan since the 1935 Hsinchu-Taichung earthquake, only few/non aftershocks occurred within the Peikang High region (shaded area in Fig. 1). Based on detailed geophysical and geological analyses, Ho (1988) indicated that the deformation characteristics of rocks in the Peikang High are significantly different from those in the surrounding areas. In addition, the presence of a low-seismicity zone within the crust might indicate that it is either stronger or more ductile than the surrounding areas (e.g., Lin 2001). However, what is the characteristic velocity feature of the Peikang High exhibited in terms of velocity structure? How does the Peikang High behave during the 1999 Chi-Chi earthquake? Would the subsurface structures of the Peikang High influenced the spatial distribution of the regional seismicity?

Previously, local earthquake tomography had been applied and mapped with differentscale velocity anomalies under Taiwan utilizing natural earthquake data (Roecker et al. 1987; Lin et al. 1993; Chen 1995; Rau and Wu 1995; Ma et al. 1996). Including large-scale of overall grid spacing greater than $20-\mathrm{km}$, these wavelength resolutions (some possible shorter) of velocity sucture may be improperly smoothed or averaged. To obtain more definitive pictures of the crustal structure of the Peikang High and its relation to the distribution of folds and faults in western Taiwan, it is worthwhile to revisit this subject with new data sets replenished by thousands of Chi-Chi aftershocks. In this study, we attempt to determine the 3-D velocity structure of the onshore and offshore area of western Taiwan by inversion of travel time data of earthquakes recorded by the Central Weather Bureau Seismographic Network (Fig. 2). It is worthy to note that the Coastal Plain is composed of Quaternary alluvial deposits derived from the Central Range and the Western Foothills. In order to obtain a reliable result of the deeper part of our velocity model, the influence of those surficial low velocity materials were also 


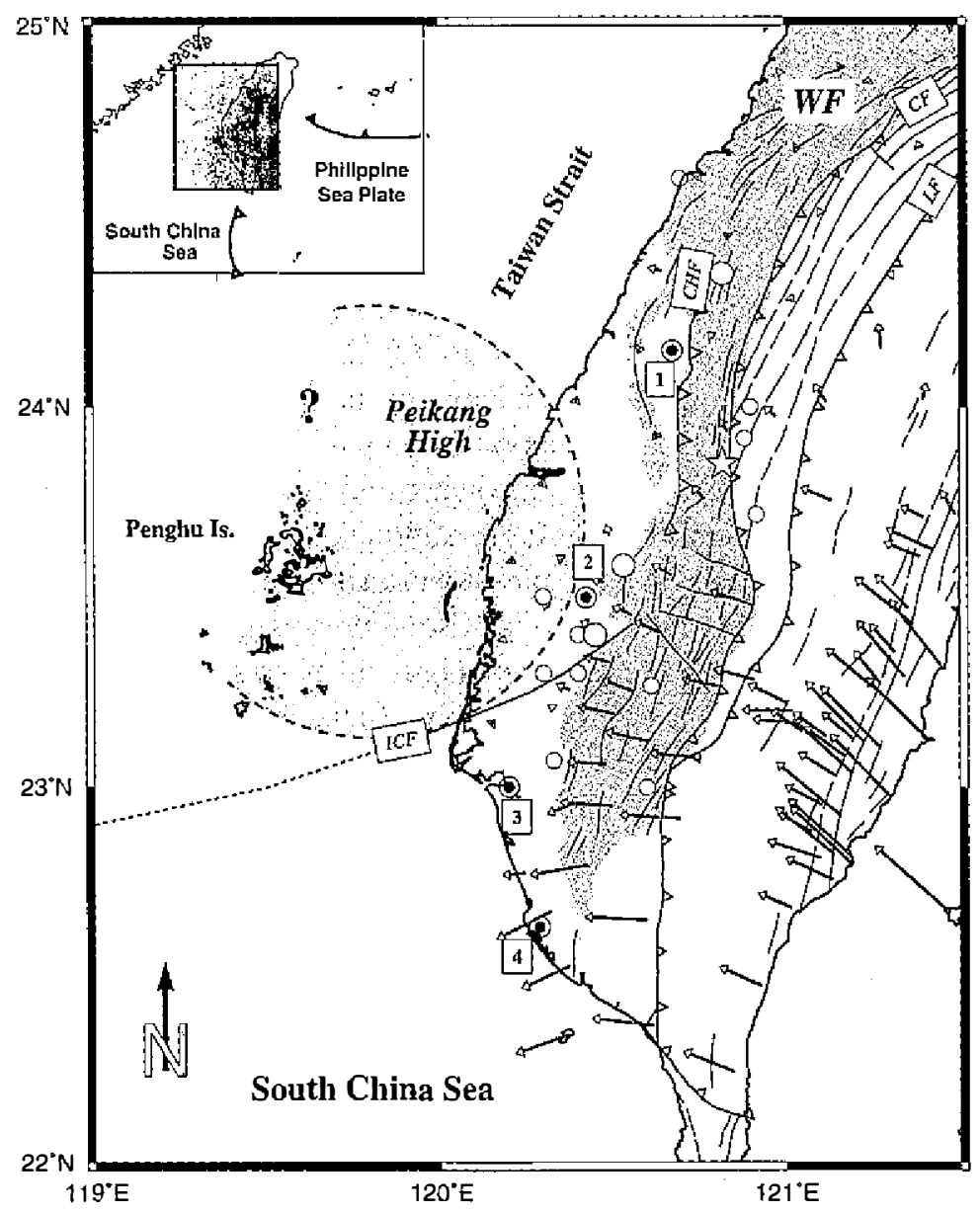

Fig. 1. A simplified tectonic map of Taiwan (geodynamic setting and regional seismicity inside the study area shown in the upper-left). Shaded area represents onshore area of the Peikang High region (Hsilo Massif in Biq 1997). Major thrust faults with open triangles on the upper side. Open star indicates the epicenter of the 1999 Chi-Chi main-shock. Arrows indicate velocities of GPS stations relative to Penghu (Yu et al. 1997). Open circles represent historical big earthquakes (Cheng and Yeh 1989). WF = Western Foothills; LF = Lisan Fault; $\mathrm{CF}=$ Chuchih Fault; $\mathrm{CHF}=$ Chelungpu Fault; ICF = Yichu Fault. $1=$ Taichung; $\mathbf{2}_{2}=$ Chiai; 3 = Tainan; [4= Kaohsiung. 
taken into consideration in the initial model. We spent much time to compile the results of drilling and reflection profiles collected by the Chinese Petroleum Corporation (e.g., Chou 1969; Chou 1973) into the initial model of the inversion performed in this study.

\section{GEOLOGICAL SETTING}

Taiwan situates at the junction of the Ryukyu arc and Luzon arc on the western margin of the Philippine Sea. In southern Taiwan, the South China Sea lithosphere is subducting eastward under the Luzon arc. In north-eastem Taiwan, the Philippine Sea plate is subducting northward under the Ryukyu arc. The formation of Taiwan island has been proposed to be the result of the oblique collision between the Luzon arc and the Eurasian plate margin (Fig. 1; e. g., Biq 1972; Chai 1972; Suppe 1981, 1984; Ho 1986; Teng 1990).

The Peikang High beneath the central part of western Taiwan is a basement horst bounded by east-striking fault zones along its northern and southern sides, and forms a rigid vertex with partial eastward tapering. Buried beneath thousands of meters of Cenozoic sediments, this huge mass of pre-Tertiary igneous and metamorphic rocks is represented on western Taiwan by a part of the vast Coastal Plain and on the Taiwan Strait (Bosum 1970; Biq 1997). The results of drilling and geophysical survey conducted by the Chinese Petroleum Corporation revealed that the Cretaceous metamorphic basement is beneath the Neogene sediment at the depths of 1463 and 1962-m in western Taiwan (Matsumoto 1965). The seismic surveys also show major segments separated by a NE-SW fault zone and a rapid transition from shailow to deeper basin from north to south (Stach 1957). Chou (1969) pointed out that the main Penghu Islands belong to the offshore extension of the Peikang Massif. From Peikang to the offshore area, the basement high also shows high gravity anomaly (Hsieh and Hu 1972).

In a WSW direction, the Peikang High extends for an oversea distance of more than 1000$\mathrm{km}$ from southeastern Taiwan to the South China Sea (e.g., Xia et al. 1994; Biq 1997). Among many subsurface faults, the mighty Yichu fault in Chiayi region marks the southern boundary of the Peikang High (Fig. 1). It is proposed that the relative movement is dextral between the Peikang High and the Western Foothills bounded by the Yichu Fault. The N-S striking frontal deformation of the central Taiwan is controlled by the hinge fault of the Peikang High (Mouthereau et al. 2002).

The 1999 Chi-Chi earthquake caused a large reverse displacement with dramatic surface ruptures along the Chelungpu fault (Fig. 1). The surface ruptures extended about $80-\mathrm{km}$ from south to north. The Chelungpu fault generally marks the boundary between the Western Foothills and the coastal plain in central Taiwan as shown by the topographical data. The coastal plain west of the Chelungpu fault, and the offshore areas are underlain by mostly flat-flying Cenozoic sedimentary sequences (e.g., Sun 1985; Juang et al. 1992; Lee et al. 1996). Thick Pleistocene conglomerate was deposited in several within the western basin suggesting a sudden uplift on the easterm border during Pleistocene (e.g., Ho 1986).

The Chuchih fault is one of the major upthrust faults that trails the contact between the Central Range slate belt and the fold-and-thrust belt of the Western Foothills (Fig. 1). The Western Foothills of central Taiwan region contains a broad zone with shallow dipping slope 
due to increase spacing between major thrust sheets (Mouthereau et al. 2002). To the west of the Chuchih fault, the Western Foothill is part of the foreland fold and thrust belt, and are underlain by thick Cenozoic siliciclastic deposits (Chou 1973; Covey 1986; Ho 1986; Ho 1988). The structures of the Western Foothills comprise a series of subparallel folds, eastdipping faults, and oblique structures. Actual fault contact is usually difficult to determine due to heavy vegetation and soil cover on the surface. The rocks are Miocene to early Pleistocene of age composed of layered sandstone and shales intercalation, which subjected to Pleistocene orogenic disturbance. The Central Range and the Hsüehshan Range on the east side of the Chuchih fault is composed of a pre-Tertiary metamorphic basement overlain by Paleogene low-grade metamorphosed sediments, folded and thrusted Neogene sedimentary layers and Quaternary alluvial deposits (e.g., Ho 1986). The Western Foothills contain a series of hills and mountains less than 1000-m in elevation. The total thickness of the cover rocks of western Taiwan reaches $8000-\mathrm{m}$ in the Western Foothills itself but rapidly declines westwardly by to only 500-m on the Penghu Islets (e.g., Ho 1986).

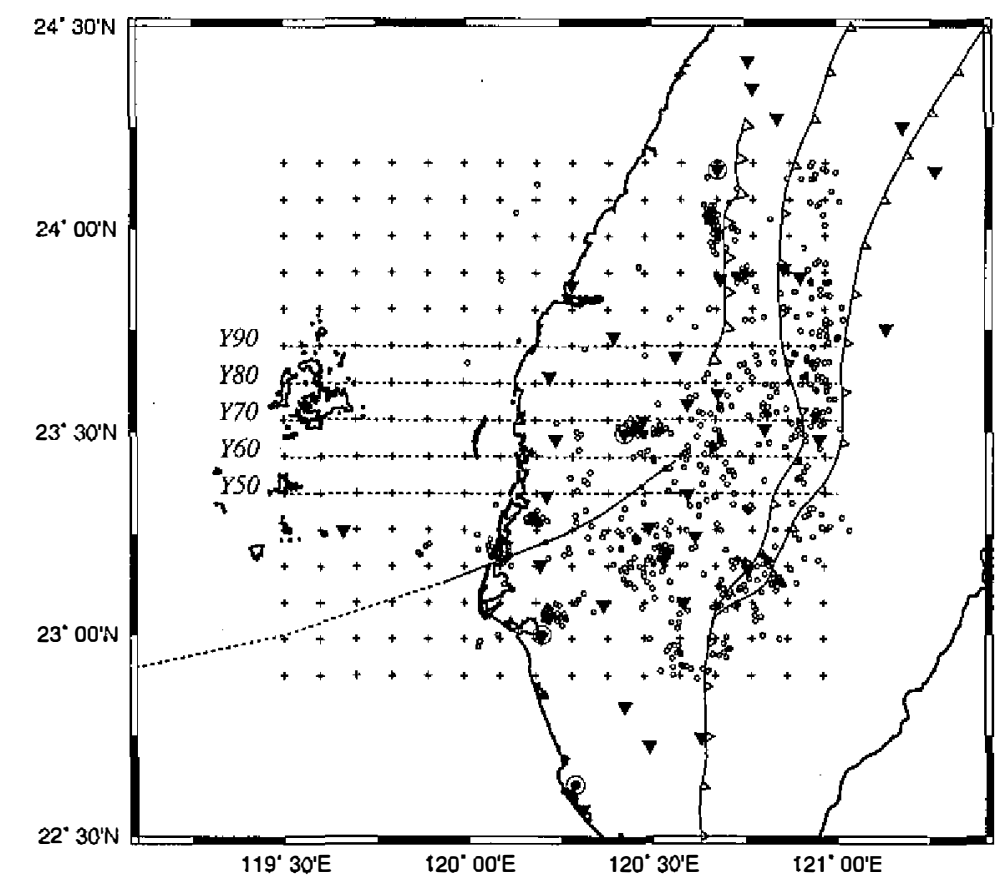

Fig. 2. Grid nodes (crosses) and earthquakes (open circles) used in the 3-D inversion. Inverted solid triangles denote permanent stations of the Central Weather Bureau Seismographic Network. Grid spacing is 10-km. Dotted lines along latitude indicate location of profiles shown in Fig. 6. 


\section{DATA AND METHOD}

The earthquake data used in this study are P- and S-wave arrival times of local earthquakes recorded by the Central Weather Bureau Seismographic Network (CWBSN) from 1991 to 1999. The CWBSN is equipped with three-component short-period digital seismographs using velocity type sensors with adjustable natural frequency from 0.75 to $1.1 \mathrm{~Hz}$, and has real-time operation in the Central Weather Bureau (CWB), Taipei (Shin 1993). Events were restricted to those with more than 10 arrival times (both P- and S-waves), and less than $180^{\circ}$ of azimuthal gap between stations. The travel time data were weighted according to their accuracy inferred from the signal-to-noise ratio of the seismic signals (weights from 1 to 0.25 for reading errors ranging from $0.01 \mathrm{~s}$ to $0.1 \mathrm{~s}$ for the $\mathrm{P}$ wave). In this study, $19840 \mathrm{P}$-arrivals and 12903 S-arrivals from 1036 earthquakes were used and presented in Fig. 2.

The tomographic inversion method applied to derive the central Taiwan 3-D velocity model was described by Thurber $(1983,1993)$ and Eberhart-Phillips (1989), and is briefly documented by Evans et al. (1994). The model is parameterized on grid of nodes with spacing of 10-km as shown in Fig. 2. We compiled travel-time data for each receiver as a function of 3D spatial location of sources, and inverted them for the 3-D velocity structure. Initial hypocenter locations and origin times of earthquakes determined by the CWB were used. Raytracing is done by using approximate 3-D algorithm with curved non-planar ray paths (Um and Thurber 1987). The velocity for a point along a ray path and the velocity partial derivatives are computed by linear interpolating between the surrounding eight grid points. Parameter separation operates on the matrix of hypocentral and velocity partial derivatives so that the hypocentral calculation is separated from the velocity calculation (Pavlis and Booker 1980). The damped least-squares approach is used to solve for velocity in inversion (Thurber 1983). In order to refine the hypocenter and determine a more reliable one-dimensional (1-D) velocity model, the VELEST program (Kissling et al. 1994) was employed. The initial 1-D velocity model is modified from Cheng (2000) and Cheng et al. (2002). In order to have a good constraint for the shallow part of the velocity model, geophysical survey and driling the results of the Chinese Petroleum Corporation are used in the initial 3-D model. We performed a tradeoff analysis (Eberhart-Phillips 1986) in order to choose the most suitable damping parameter for the damped least-squares inversion.

Standard approaches to obtain meaningful and reliable interpretations of tomographic results comprise the use of synthetic tests including checkerboard tests (e.g., Bijward et al. 1998) and resolution estimates (e.g., Thurber and Eberhart-Phillips 2000) by spread function, hit count, and diagonal elements of the resolution matrix. Zhao et al. (1992) used restoring resolution test to estimate the capacity of the data set to resolve geometry and amplitude. Although our data retained the size and amplitude of anomalies seem in the inversion results by the restoring resolution test, but the geometry and the sign of velocity variation used are different in the characteristic model (Fig. 3). Synthetic travel-times were computed by 3-D ray tracing method (Um and Thurber 1987) using the same source-receiver distribution as for the real data with the same model parameterization. Comparison between the inversion results (Fig. 4) with the synthetic input model (Fig. 3) allows identification of well-recovered areas. On the other hand, checkerboard tests can provide valuable information about damping, 
model parameterization, and resolution capability of the data set (Zhao et al. 1992). In this paper, positive and negative velocity anomalies of 5\% were assigned to 3-D grids of a velocity model with same grid spacing. Synthetic travel times calculated for the checkerboard model using the same numbers of events, stations, and ray paths in the real data set. We added random errors of 0.02 to $0.1 \mathrm{~s}$ as in the real data to the synthetic data, and inverted them with the same algorithm as we did for the real data. Therefore, by comparing the image of the synthetic inversion of the checkerboard model, we can determine where the solution is good and where is poor.

In order to justify the ray coverage for offshore area, we also plotted the ray paths which penetrated the velocity model. Figure 5 shows the ray paths from hypocenters to the PNG and WDG stations deployed in Penghu and Tongchi islets. Comparison between the inversion results (Fig. 4) with the synthetic input model (Fig. 3) and the ray coverage (Fig. 5) allows us to identify well-resolved areas.

\section{RESULTS}

The 3-D velocity model is displayed in map views for $1,5,10,15,20$, and $25-\mathrm{km}$ of depth in Fig. 6. As shown in Figs. 4 and 5, the resolution is good for the southern part of the onshore area in study area. From $z=1$ and $z=5 \mathrm{~km}$ slices, the dominant feature in the velocity model is relatively low $\mathrm{Vp}$ zone ranging from about 2.5 to $5 \mathrm{kms}^{-1}$ generally distributed west of the Chuchih fault. The most striking feature in the $3-\mathrm{D}$ velocity model is the high velocity dome extending downward from about $10-\mathrm{km}$ in depth into lower crust beneath the coastal area which should be associated with the Peikang High. This high velocity volume is overlaid with low velocity material in western Taiwan area. At $\mathrm{z}=10 \mathrm{~km}$, the velocity of this high $\mathrm{Vp}$ volume varies from 6 to $6.5 \mathrm{kms}^{-1}$ (Fig. $6 \mathrm{c}$ ). The restoring test also indicated high resolution for this high $\mathrm{Vp}$ feature.

Figure 7 shows the 3-D velocity structure in a series of E-W cross-sections. The locations of the velocity profiles in Fig. 7 are shown in Fig. 2 . Taking the $5 \mathrm{kms}^{-1}$ velocity contour as the consolidated sediments/basement contact, it seems that the Peikang High might have extended eastwards in front of the Western Foothills. The other higher $\mathrm{Vp}$ feature is observed in the area east to the Chuchih fault between $10-\mathrm{km}$ to $15-\mathrm{km}$ depth intervals beneath the Central Range. Between these two upper crustal high-velocity volumes, the 3-D velocity model shows a large region of low Vp between the Central Range and Peikang High (relatively low Vp area in Fig. $7 c)$.

At shallow depth where the geological data and the 3-D velocity model overlap, agreements between the 3-D velocity models and geological data confirms the validity of the 3-D Vp model. The overall basinal shape of the Coastal Plain near the surface is reflected in the velocity model as shown in Fig. 7.

About 5794 aftershocks of the 1999 Chi-Chi earthquake with magnitude $\geq 2.5$ were relocated with the 3-D velocity model obtained in this study (open circles in Figs. 6 and 7). The velocity-hypocenter inversion program (Thurber and Eberhart-Phillips 2000) was used to relocate the 3-D locations of the Chi-Chi aftershocks. The RMS residuals for the relocated hypo- 
centers ranged from 0.01 to $0.44 \mathrm{~s}$ with an average of $0.178 \mathrm{~s}$ and a standard deviation of 0.013 s. The weighted RMS residual changed from about 0.274 for $1-\mathrm{D}$ locations to about 0.178 for 3-D locations. The relocated hypocenters show a more clustered distribution than the 1-D locations.

To interpret the results, we plot a series of cross sections of the final 3-D velocity model parallel to latitudinal lines of western Taiwan (Fig. 7). On the basis of the checkerboard test on the right side of each section, areas with good resolution in Fig. 7 are shown with big solid or open hexagons, whereas areas with fair resolution are shown with small ones. The velocity structure of the southern part of offshore in the study area has good resolution. Thus, a detailed interpretation of the Peikang High, relocated seismicity, and their implication for the seismogenic zone could be discussed.

\section{DISCUSSION}

\subsection{Peikang High}

This study obtains a 3-D velocity model of the Western Foothills, Coastal Plain, and offshore areas providing the third dimension of the western Taiwan area. Beneath the Coastal Plain and offshore area, a prominent high-velocity anomaly in the middle- to lower-crust was indicated. This uplift high velocity volume should be associated with the Peikang High (dashed lines in Fig. 7). This high velocity zone is overlaid by a basin type of low velocity materials, the Coastal Plain. It also shows that the upper crust is thinner than the lower crust in this area. East of $120.2^{\circ} \mathrm{E}$, the 3-D velocity model reveals a broad relatively low-velocity zone in the upper- and middle-crust under the Western Foothills. The relocated hypocenters of Chi-Chi aftershocks shown in Fig. 7 indicate that most of them located within this low velocity area beneath the Western Foothills.

On the other hand, the Peikang High is an earthquake quiescent zone even after the ChiChi mainshock (Figs. 6 and 7). The origin of how map-view curves (including salients, recesses, arcs, oroclines, and bends) in fold-thrust belts has caught the attenuation of geologists for a long time. Macedo and Marshak (1999) proposed that the majority of curved fold-thrust belts are "basin-controlled" in that their presence reflects along-strike variations in the width of fold thrust belts. For example, thrusts in basin-controlled curves as well as in curves formed in front of indenters can initiate in response to interactions with foreland obstacles or with strikeslip faults display oroclinal bending (Marshak et al. 2002). The velocity contrast between Peikang basement high and Western Foothills, about $0.5 \mathrm{kms}^{-1}$ (Fig. 6c), suggested different lithology material for these regions. In addition, the hypocenters of moderate-sized and large earthquakes at seismogenic depths from 10 to $20 \mathrm{~km}$ were recorded outside the high Vp zone of the Peikang High (Fig. 6). It can be interpreted as the materials of the Peikang High are more homogeneous and more competent to sustain stresses from high levels of seismicity. In other words, the nature of crustal composition and the subsurface geometry of the Peikang High would have certainly influenced the spatial distribution of regional seismicity.

In order to estimate the possible rock source of the Peikang High, we compared the depth- 
(a) $\mathrm{Z}=5 \mathrm{~km}$

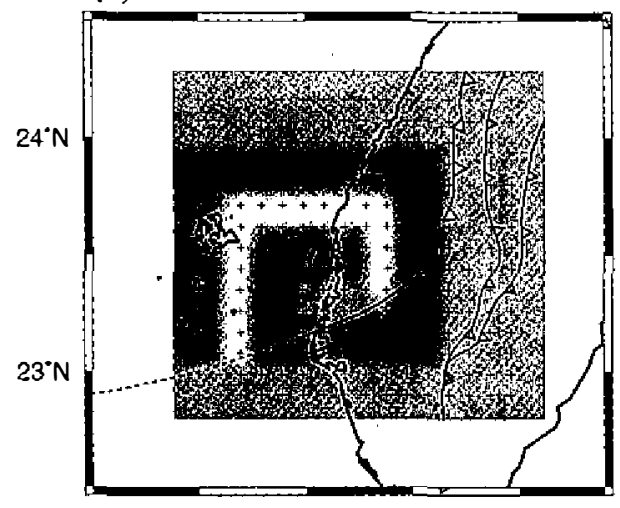

(b) $\mathrm{Z}=10 \mathrm{~km}$

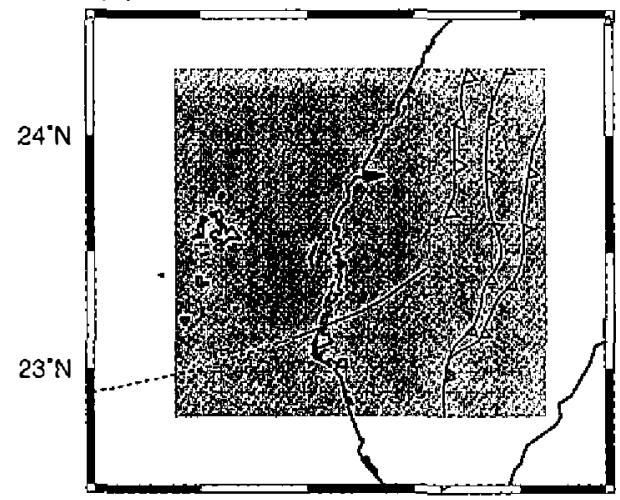

(c) $\mathrm{Z}=15 \mathrm{~km}$

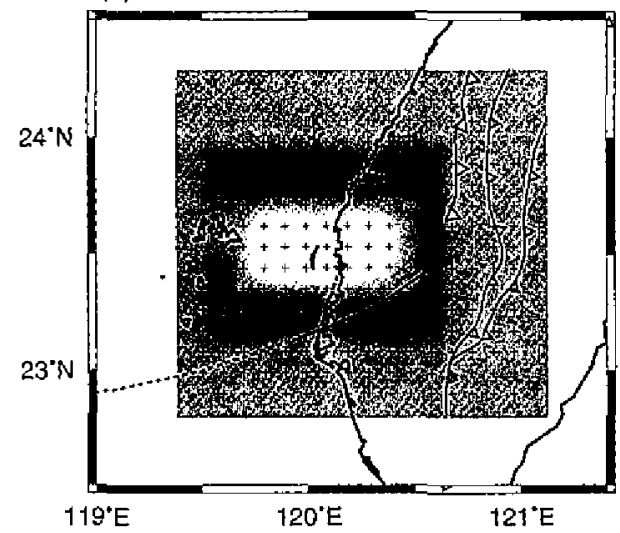

(d) $\mathrm{Z}=\mathbf{2 0} \mathrm{km}$

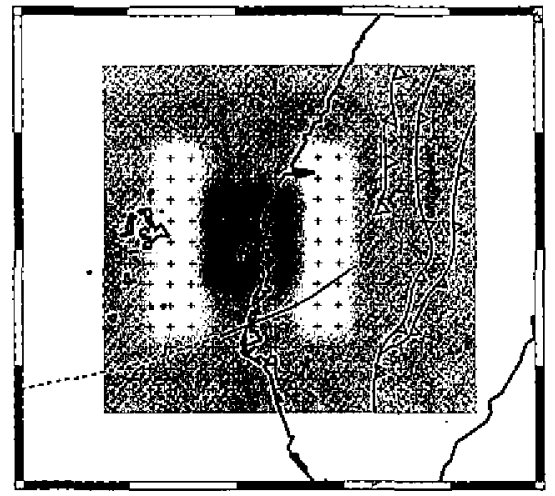

(e) $\mathrm{Z}=\mathbf{2 5} \mathrm{km}$
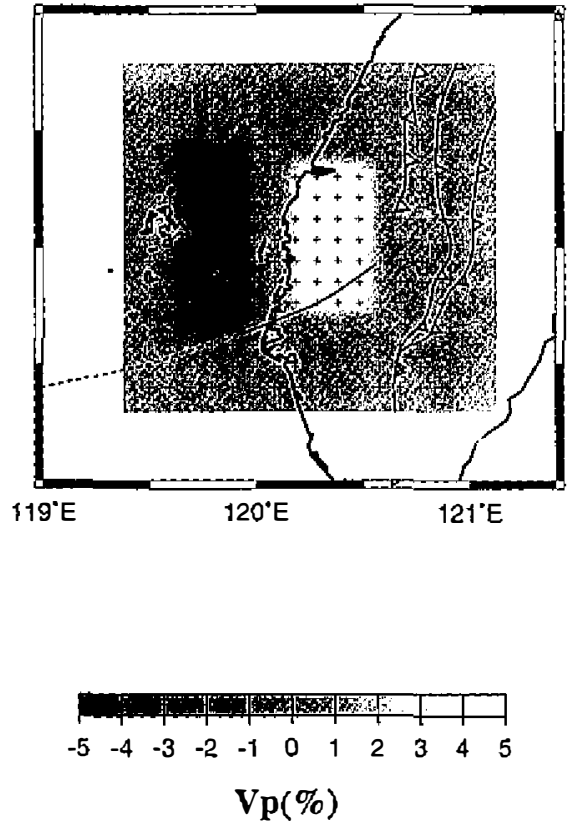

Fig. 3. Horizontal depth sections of characteristic model used to compute synthetic ravel times. The velocity perturbation scale is shown at the bottom. Small crosses denote grid nodes. 
(a) $\mathrm{Z}=5 \mathrm{~km}$

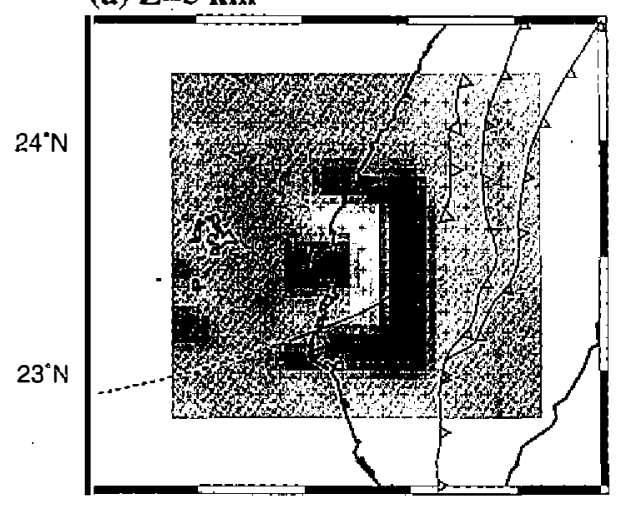

(b) $\mathrm{Z}=10 \mathrm{~km}$

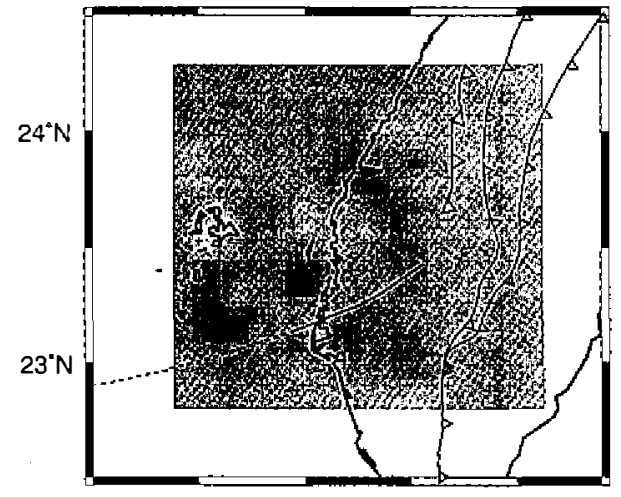

(c) $\mathrm{Z}=\mathbf{1 5} \mathrm{km}$

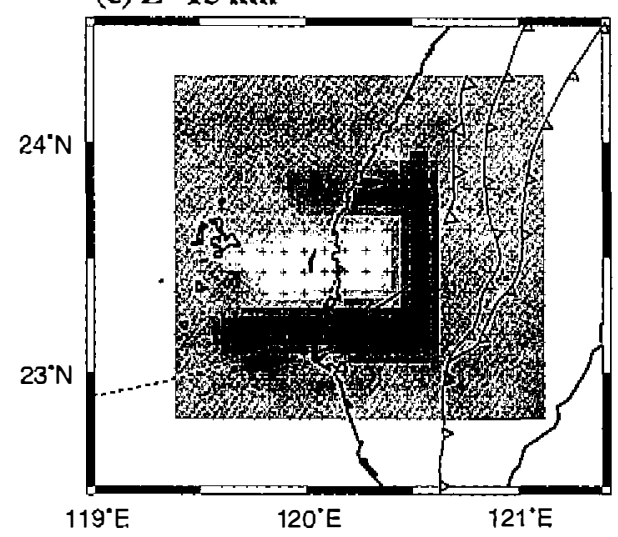

(d) $\mathrm{Z}=20 \mathrm{~km}$

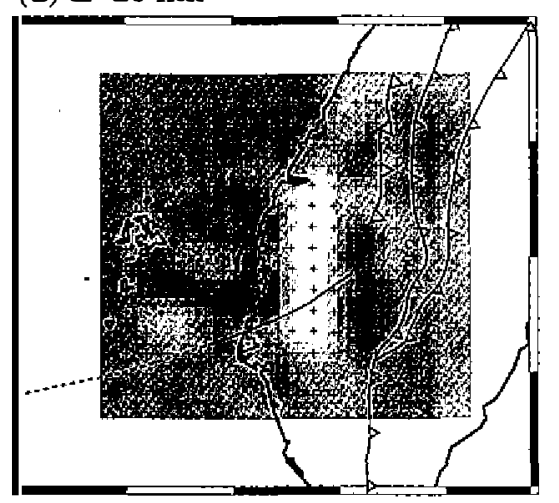

(e) $\mathrm{Z}=25 \mathrm{~km}$
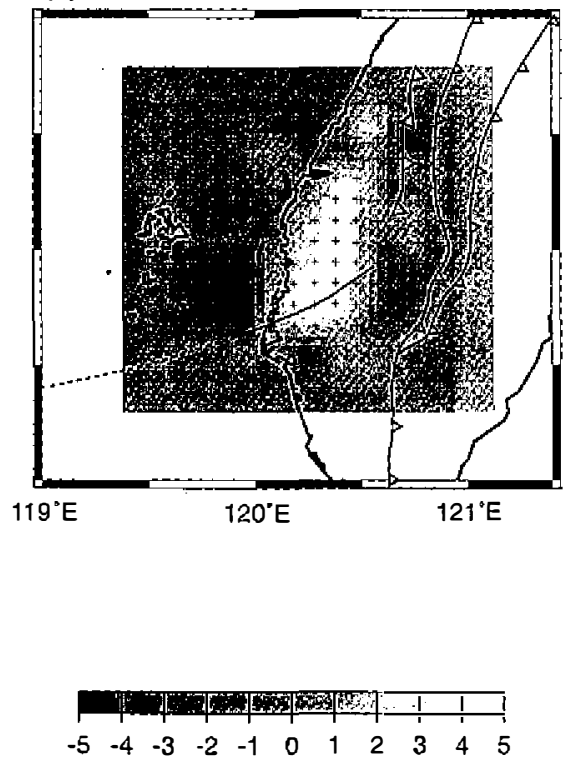

$\mathrm{Vp}(\%)$

Fig. 4. Inversion results for the synthetic travel time data set of the synthetic - model shown in Fig. 3. The velocity perturbation scale is shown at the bottom. Small crosses denote grid nodes. 
(a)
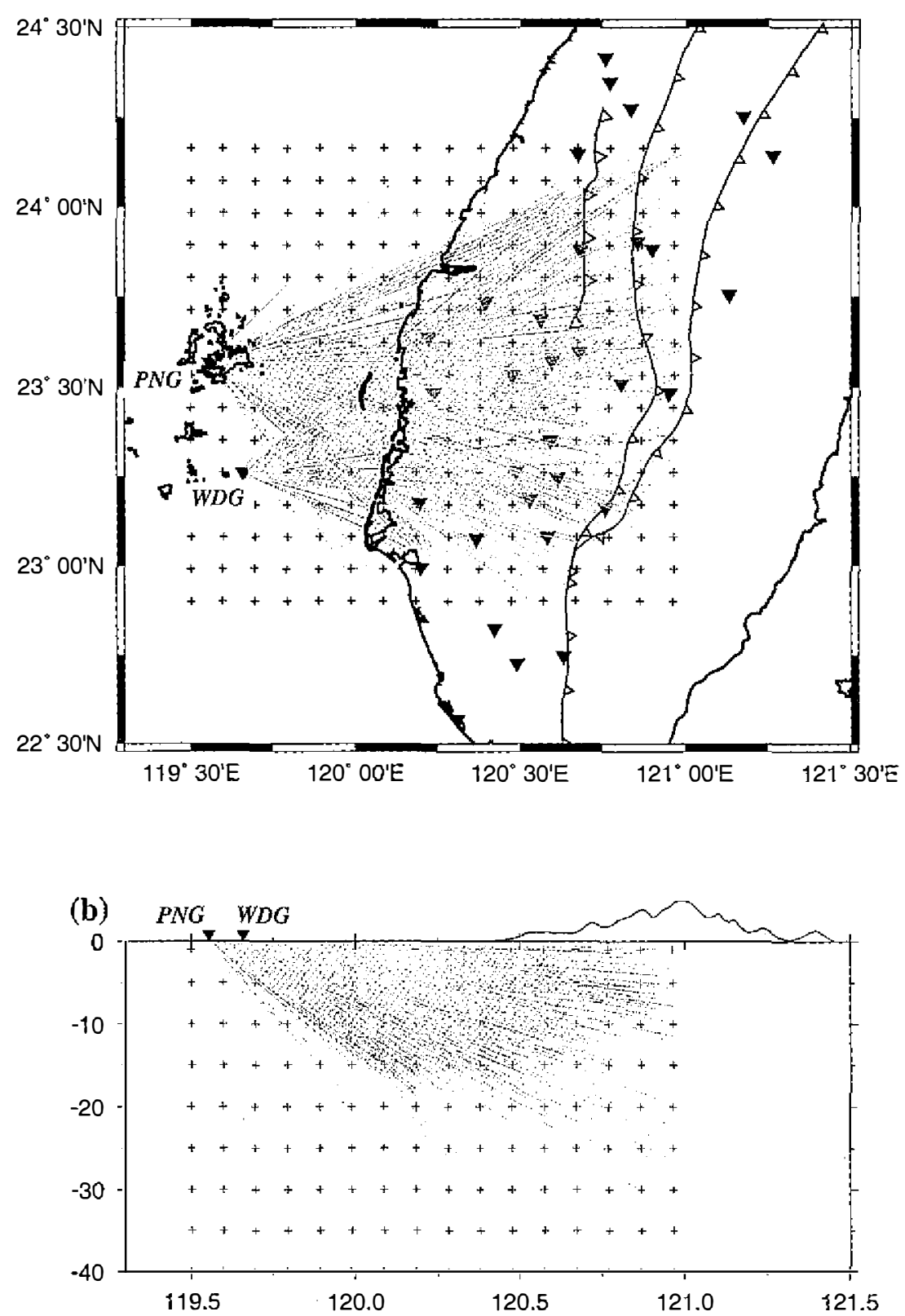

Fig. 5. Ray paths from hypocenters of the used events to PNG and WDG stations in map-view (a) and cross-section (b). 
(a) $\mathrm{Z}=\mathbf{1} \mathrm{km}$
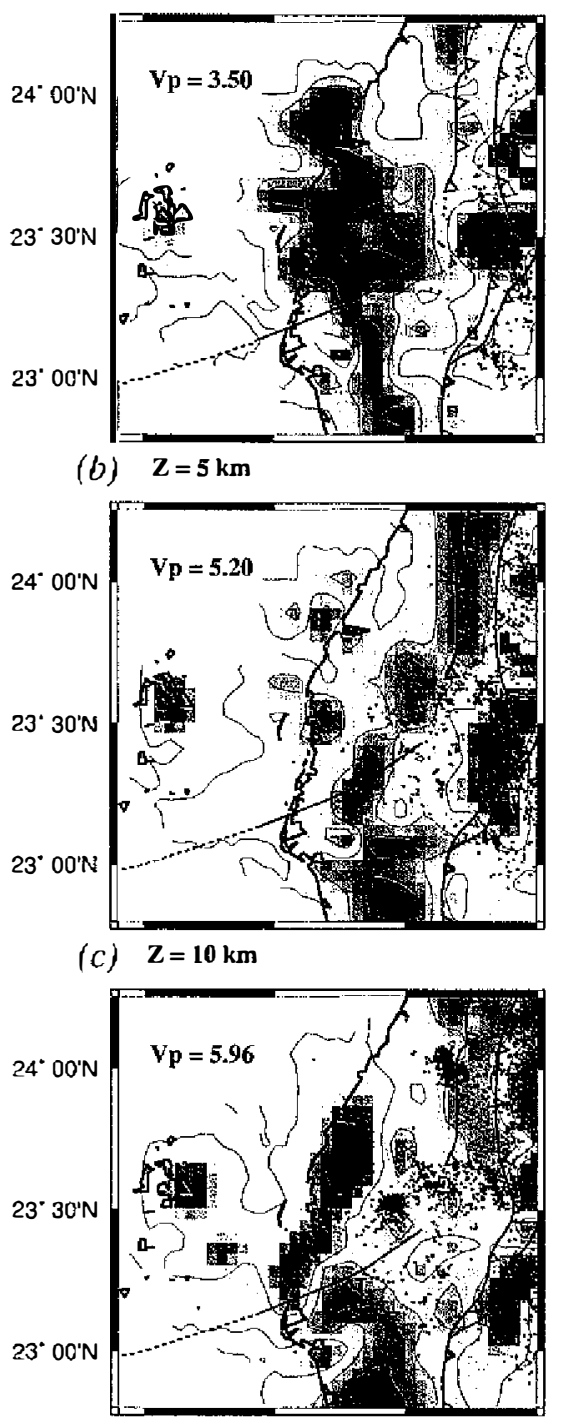

$119^{\circ} 30^{\circ} \mathrm{E} \quad 120^{\circ} 00^{\prime} \mathrm{E} \quad 120^{\circ} 30^{\circ} \mathrm{E} \quad 127^{\circ} 00^{\circ} \mathrm{E}$ (d) $\mathrm{Z}=15 \mathrm{~km}$

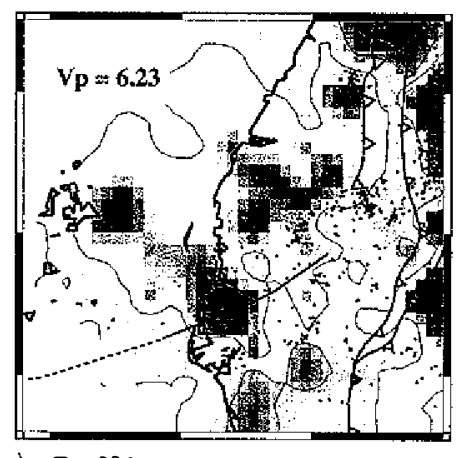

(e) $\mathrm{Z}=20 \mathrm{~km}$

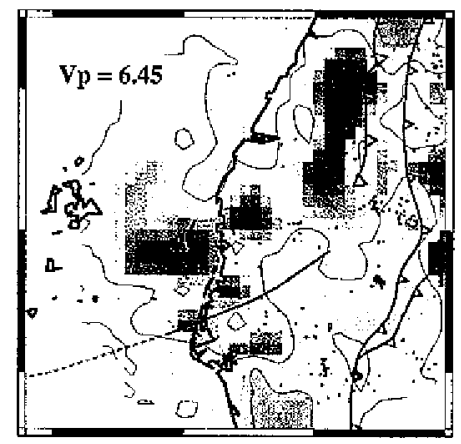

(f) $\mathbf{Z}=\mathbf{2 5} \mathrm{km}$

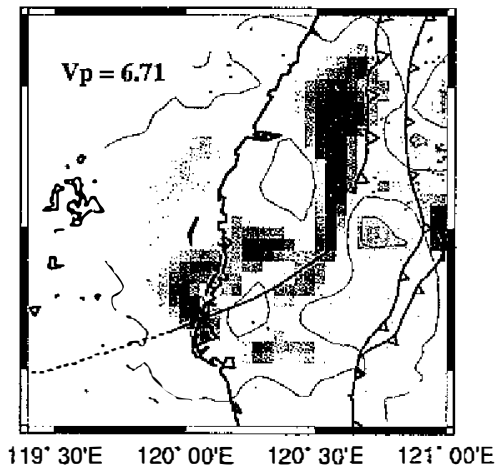

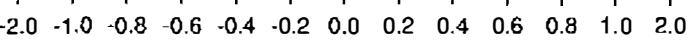

Vp Perturbation ( $\mathrm{km} / \mathrm{s})$

Fig. 6. Results of three-dimensional P-wave velocity model shown in map-view at depths of (a) $1 \mathrm{~km}$, (b) $5 \mathrm{~km}$, (c) $10 \mathrm{~km}$, (d) $15 \mathrm{~km}$, (e) $20 \mathrm{~km}$, and (f) $25 \mathrm{~km}$. Contour interval is $0.2 \mathrm{kms}^{-1}$. Relocated hypocenters (small circles) of the Chi-Chi aftershocks are shown. The velocity perturbation scale is shown at the bottom. See Fig. 1 for identification of faults and Fig. 2 for map orientation. 
velocity profile of the Peikang High (Fig. 8) with the measured wave velocities of rocks under specific pressure-temperature conditions reported in the literature (Christensen 1965; Kern 1978; Christensen 1979; Christensen and Mooney 1995). Because the crustal geothermal structure is important for the interpretation of seismic velocity distribution, we first constructed the temperature-depth model for the study area based on the thermal gradient values calculated from extrapolations of heat flow measurements in Taiwan area reported by Lee and Chang (1986). Since there are no experimental data for the temperature/pressure function for the rocks in this area, we have therefore used the experimental P-wave velocities of many rocks collected by Christensen and Mooney (1995) at specific temperature-depth relation to estimate the possible composition of the Peikang High. When we superposed the velocity-depth distribution of the Peikang High on those from Christensen and Mooney (1995), it shows that the possible rock composition of the middle crust is different to that of the lower crust beneath Peikang High. There are several rocks (e.g., slate, biotite gneiss, mica quartz schist, paragranulite, and felsic granulite) are located within the velocity range of the Peikang High within 10 to 20$\mathrm{km}$ of depth composition. Alternatively, diabase, amphibolite, and mafic granulite are possible rock for the Peikang High in lower crust (Fig. 8). This suggests that the possible lower crust composition of the Peikang High might be a mixture of igneous and low- to intermediate-grade metamorphic rocks. On the other hand, the middle crust of the Peikang High is possibly constructed with intermediate-grade metamorphic rocks.

The obliquity of convergence between the Eurasia and the Philippine Sea plate collision occurs near the transition between oceanic and continental crusts within the subducting of the South China Sea plate and the island of Taiwan. Wang et al. (2002) proposed a model of Solitary wave to investigate the southward propagation of mountain building according to magnetic and seismological evidences. In this model, the presence of Peikang High is likely to play as a barrier in the southwards development of the mountain belt. In addition, from studies
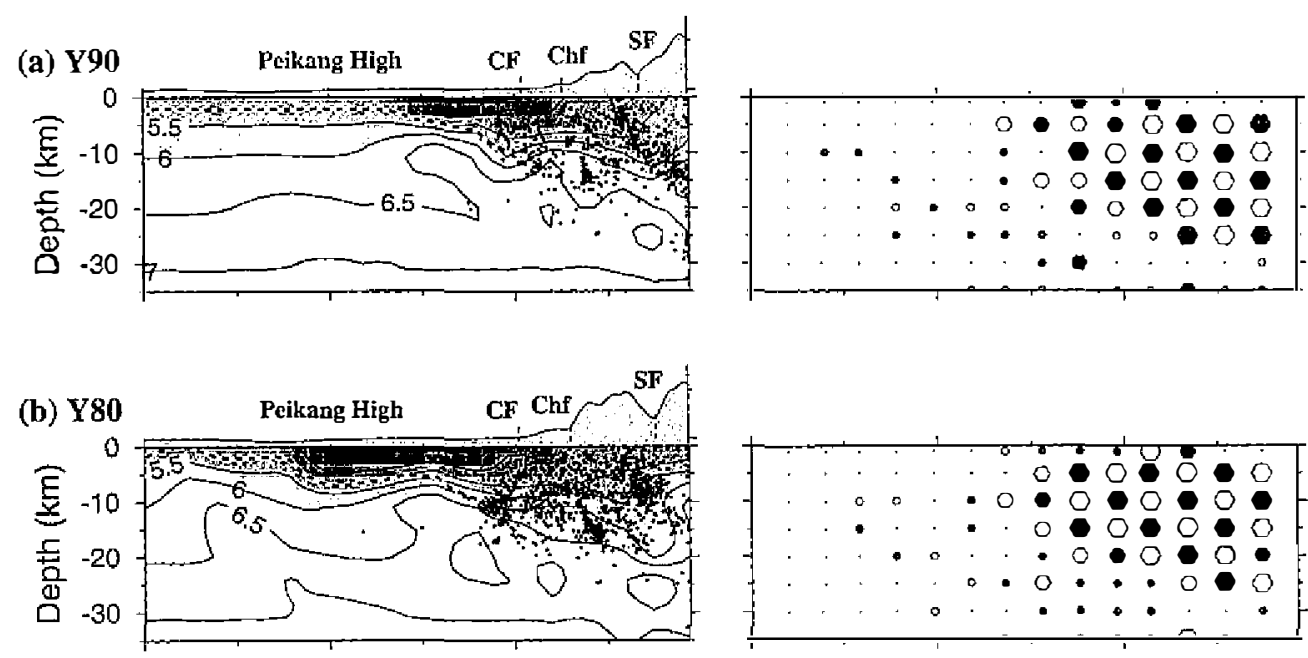

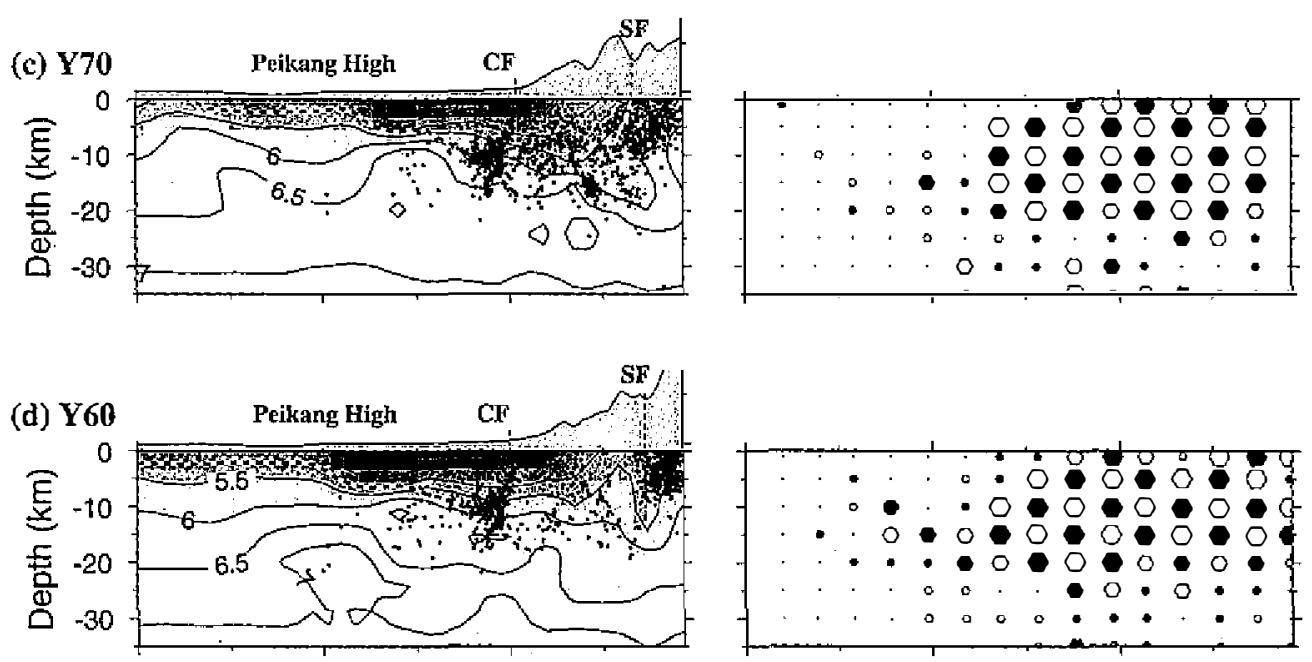
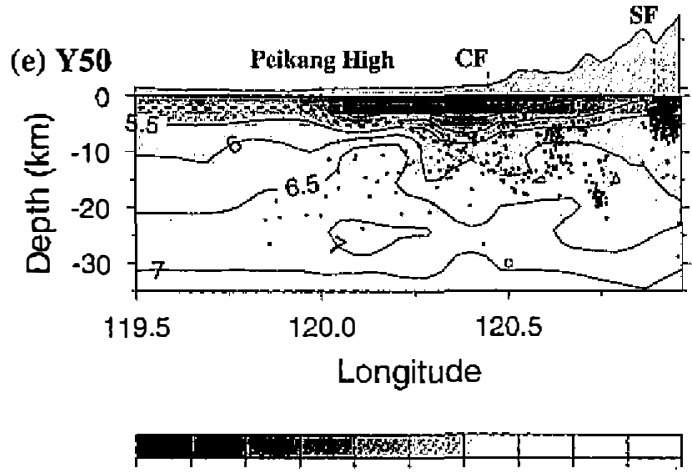

$\begin{array}{lllllllllll}2.5 & 3.0 & 3.5 & 4.0 & 4.5 & 5.0 & 5.5 & 6.0 & 6.5 & 7.0 & 7.5\end{array}$ $\mathrm{Vp}(\mathrm{km} / \mathrm{s})$

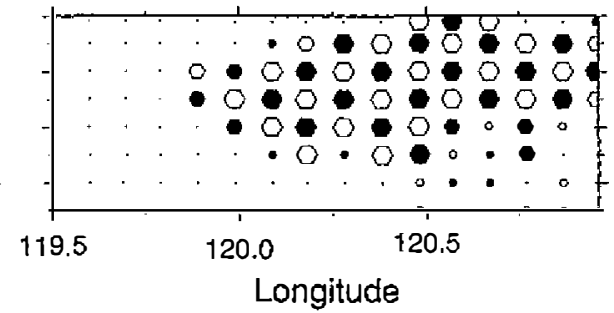

$\begin{array}{cccc}-5 \% & -0 \% & 0 & 0 \\ 0 \% & +5 \%\end{array}$

Fig. 7. Inversion E-W cross sections plus results of checkerboard resolution test. (left) Cross-sections of 3-D velocity structure contoured at $0.5 \mathrm{kms}^{-1}$ intervals and along (a) Y90, (b) Y80, (c) Y70, (d) Y60, and (e) Y50 section as shown in Fig. 2. Topography of each cross-section is shown on top. The possible ramps of the sub-surface Peikang basement are delineated with the 5.0 contours (dashed lines). Vertical exaggeration is 1:1. Relocated hypocenters (small circles) of the Chi-Chi aftershocks are projected horizontally onto the planes of sections from about 10-km on either side. The velocity perturbation scale is shown at the bottom. (right) Results of checkerboard resolution test describing resolution. Well-resolved and spatially well-constrained velocity grids are shown with big solid and open hexagons. Small hexagons indicate little information, and velocity value is close to initial value. $\mathrm{ChF}=$ Chelungpu Fault; $\mathrm{CF}=$ Changhua Fault; $\mathrm{SF}=$ Sweilikun Fault. 
of earthquake activities and physical modeling, the Peikang High has also affected the regional stress pattern (e.g., Hu et al. 1997), regional seismicity (e.g., Wang and Shin 1998), and spatial pattern of the Ch-Chi aftershock (e.g., Wang et al. 2000). The Peikang High is also important in understanding of tectonic evolution of the South China Sea because it is part of a major magnetic and gravity high area, which might characterize the northeastward extension of Dongsha Rise in the northem margin of the South China Sea (e.g., Xia et al. 1994; Hayes et al. 1995; Yao et al. 1994; Yao 1998). A number of speculations, e.g., micro-continental blocks (K. C. Xia, per com.), volcanic arcs (K. C. Xia, per com.), subduction zone (e.g., Hayes et al. 1995), and suture zone (e.g., Yao et al. 1994; Yao 1998) have been discussed for the formation of the Dongsha Rise. Velocity sections of the Peikang High with well resolution shown in Figs $7 \mathrm{c}$, d had been compared with velocity sections of the Dongsha Rise obtained in several studies (Nissen et al. 1995; Kinoshita et al. 1996; Yao 1998). We found that a high velocity material in the lower crust of velocity structure both exist in the Peikang High and Dongsha Rise. The upper crust is also thinner than the lower crust (Yao 1998). However, Fig. 7 also indicated that the resolution of the velocity structure is poor for the northern part of offshore area. Thus we proposed that by combining the gravity modeling and seismic velocity inversion for the western Taiwan offshore area may serve a better understanding on the crustal structures and their relationship between the Peikang High and Dongsha Rise.

\subsection{Relationship of Aftershock Seismicity and Faults to Velocity Structure}

From historical earthquake study (open circles in Fig. 1) and the epicenter of 1999 ChiChi earthquake, most of the destructive earthquakes in western Taiwan occurred in vicinity or within the Western Foothills. In addition, the Chi-Chi aftershocks did not spread out beneath the central Taiwan but concentrated in some limited regions. Since the distribution of aftershock seismicity of the Chi-Chi earthquake, which often represents part of the crustal deformation in the brittle upper crust, is roughly consistent with semi-circular shape of the Peikang High, the apparent contrast of aftershock seismicity around the Peikang High might imply that crustal strength in the Peikang High is probably stronger than in those surrounding areas (e.g., Hu et al. 1997; Lin 2001). Thus, investigation of the relationship between seismicity and velocity structure of the Peikang High would provide us some information on the seismogenesis of the Chi-Chi aftershocks. Figure 6 shows the P-wave velocity structure of the western Taiwan in map view with relocated hypocenters of the Chi-Chi aftershocks. The low Vp zone of the Western Foothills seems to be limited within two high Vp zones in the upper- to middlecrust east of the Chuchih fault and west of $120.5^{\circ} \mathrm{E}$ (see best in Fig. 6c). As mentioned above, many of the shallow aftershocks in the upper and middle crust occurred in the low velocity areas of the Western Foothills (Figs. 6a, b, c, d). The Western Foothills composed of layered Miocene to early Pleistocene sandstone and shale intercalation sediments, might have large region with high pore pressure, which could influence rupture nucleation (Sleep and Blanpied 1992). The results of our study propose that the extent of the rupture area of the Chi-Chi earthquake might be limited by the presence and the geometry of the Peikang High, and the structural orientation of the Western Foothills.

Mooney et al. (1998) reported that the P-wave velocity is $2.0-3.0 \mathrm{kms}^{-1}$ in unconsolidated 


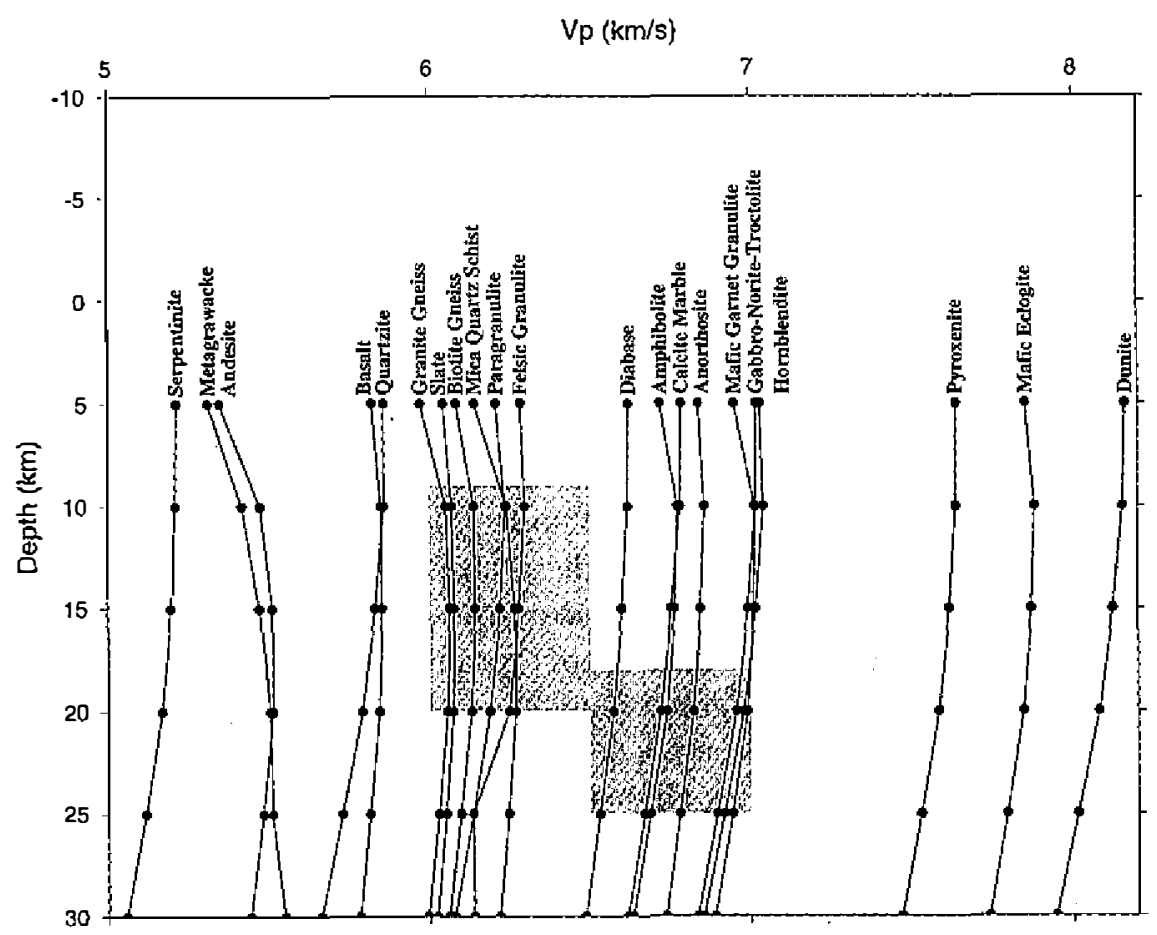

Fig. 8. Velocity-depth distribution of Peikang High (shaded area) compared to average laboratory measured velocities in major rock types reported by Christensen and Mooney (1995).

(soft) sediments and is 4.0-5.3 $\mathrm{kms}^{-1}$ in the consolidated (hard) continent layers. Metamorphosed Paleozoic sediments are included as part of the upper crystalline crust on the basis of their seismic velocity $\left(>5.0 \mathrm{kms}^{-1}\right)$ in many regions. On the vertical depth-sections (Fig. 7), the $5 \mathrm{kms}^{-1}$ contours might indicate the transition from sedimentary material to the top of Peikang High massif. The hypocentral locations of the Chi-Chi aftershocks appear to occur above the 5 $\mathrm{kms}^{-1}$ contours as shown in Fig. 7. If the slopes of the $5 \mathrm{kms}^{-1}$ contours represent the ramps of the Peikang High, it means that they would create a regional subhorizontal décollement or thrust faults. Besides, structural inversion found in Taiwan mountain-belt front is associated with basement-involved deformation in the inner domain indicated that presence of deep décollement and is continuous beneath the foreland (Mouthereau et al. 2002). However, spatial distribution of the Chi-Chi aftershocks did not indicate a concentration along the ramps of the Peikang High. Numerous studies (e.g., Ouyed et al. 1983; King and Yielding 1984; EberhartPhillips 1989; Cheng 2000) show that thrust earthquake can have a range of structures indicated by their aftershocks and secondary faults. Secondary structures including conjugate faults, and imbricate faults as well as strike-slip faults. For a particular thrust earthquake, one type of 
secondary faulting or aftershocks may be evident primarily in the hanging wall or footwall. These differences between earthquakes may be due to differences in rock type of the Peikang High and Western Foothills or preexisting structure in the western Taiwan.

\section{CONCLUSIONS}

We determined three-dimensional P-wave velocity structure of the western Taiwan area by using seismic tomography and local earthquakes. In particular, this paper has illustrated the sub-surficial geometry of the Peikang High and its influence on the distribution of surficial faults in western Taiwan and Chi-Chi aftershocks.

The sub-surface of Peikang High can be interpreted with obvious high Vp volume from about 10-km in depth to lower-crust beneath the onshore/offshore area of western Taiwan. The possible ramps of the Peikang High mainly consists a set of east dipping planes represented by the $5 \mathrm{kms}^{-1}$ contours of velocity sections which marks a transition from sedimentary material to the top of Peikang High massif. From the locations of the possible ramps of the Peikang High, it is suggested that the shortening of the upper crust in western Taiwan is associated with the distribution of the high velocity materials of the Peikang High. In turn, the upper crust shortens by creating folds and faults and by creating topography.

The superposition of cross sections on the obtained three-dimensional velocity model and the three-dimensional relocations of the aftershocks of the 1999 Chi-Chi earthquake show some consistencies. At seismogenic depths from upper to middle crust, the hypocenters of moderate-sized and large earthquakes were occurred in or adjacent to lower velocity regions between the Central Range and aseismic Peikang High.

Acknowledgments The authors are grateful to the Seismological Observation Center, Central Weather Bureau, for providing earthquake data. Help from the Chinese Petroleum Corporation is gratefully acknowledged. We are also thankful to Drs. B. Y. Kuo, C. S. Lee, and S. K. Hsu for their valuable discussion. We wish to thank two anonymous reviews for their critical points, thoughtful comments and careful reviews of this paper. The research was supported by the National Science Council of the Republic of China, under grant NSC 90-2116-M-228-001.

\section{REFERENCES}

Barrier, E., and J. Angelier, 1986: Active collision in eastern Taiwan: the Coastal Range. Tectonophysics, 125, 39-72.

Bijward, H., W. Spakman, and E. R. Engdahl, 1998: Closing the gap between regional and global travel time tomography. J. Geophys. Res., 103, 30055-30078.

Biq, C., 1972: Dual-trench structure in the Taiwan-Luzon region: Proceedings of Geological Society of China, 15, 65-75.

Biq, C., 1997: Encyclopedia of European and Asian regional geology. Edited by E. M. Moores and R. W. Fairbridge, Chapman and Hall, Londan, pp. 711-717.

Bosum, W., G. D. Burton, S. H. Hsieh, E. G. Kind, A. Schreiber, and C. H. Tang, 1970: 
Aeromagnetic survey of offshore Taiwan. UN ECAFE CCOP Tech . Bull., 3, 1-34.

Chai, B. H. T., 1972: Structure and tectonic evolution of Taiwan. Am. J. Sci., 272, 289-442.

Chen, Y. L., 1995: Three dimensional velocity structure and kinematics analysis in Taiwan area [Master's thesis]. Chung-Li, Taiwan, National Central University, 172 p. (in Chinese).

Cheng, S. N., and Y. T. Yeh, 1989: Catalog of the earthquake in Taiwan from 1906 to 1988. Inst. Earth. Sci., Academic Sinica, IES. R-661, 255pp.

Cheng, W. B., 2000: Three-dimensional crustal structure around the source area of the 1999, Chi-Chi earthquake in Taiwan and its relation to the aftershock locations. TAO, 11, 643-660.

Cheng, W. B., C. Wang, C. T. Shyu, and T. C. Shin, 2002: Crustal structure of the convergent plate-boundary zone, eastern Taiwan, assessed by seismic tomography. Geological Society of America Special Paper, 358, 161-176.

Chou, J. T., 1969: A perographic study of the Mesozoic and Cenozoic rock formations in the Tungliang well TL-1 of the Penghu Islands, Taiwan. China: U. N. ECAFE Comm. For Coordination of Joint Prospecting for Mineral Resources in Asia Offshore Areas (CCOP). Tech. Bull., 2, 97-115.

Chou, J. T., 1973: Sedimentary and paleogeography of the upper Cenozoic system of western Taiwan. Pet. Geol. Taiwan, 16, 111-143.

Christensen, N. I., 1965: Compressional wave velocities in metamorphic rocks at pressures to 10 kbar. J. Geophys. Res., 70, 6147-6164.

Christensen, N. I., 1979: Compressional wave velocities in rocks at high temperatures and pressures, critical thermal gradients, and crustal low velocity zones. J. Geophys. Res., 84, 6849-6857.

Christensen, N. I. and W. D. Mooney, 1995: Seismic velocity structure and composition of the continental crust: a global view. J. Geophys. Res., 100, 9761-9788.

Covey, M., 1986: The evolution of foreland basins to stedy state: evidence from the western Taiwan foreland basin. In: P.A. Allen and P. Homewood (Editors). Foreland Basins. Int. Assoc. Sedimentol. Spec. Publ., 8, 77-90.

Eberhart-Phillips, D., 1986: Three-dimensional velocity structure in northern California Coast Ranges from inversion of local earthquakes arrival times. Bull. Seism. Soc. Am., 76, 1025-1052.

Eberhart-Phillips, D., 1989: Active faulting and deformation of the Coalinga anticline as interpreted from three-dimensional velocity structure and seismicity. J. Geophys. Res., 94, 15565-15586.

Evans, J. R., D. Eberhart-Phillips, and C. H. Thurber, 1994: User's manual for SIMULPS 12 for imaging $\mathrm{Vp}$ and $\mathrm{Vp} / \mathrm{Vs}$ : A derivative of the "Thurber" tomographic inversion SIMUL3 for local earthquake and explosions. U.S. Geol. Surv. Open File Rep., 94-431.

Hayes, D. E., S. S. Nissen, P. Buhl, J. Diebold, B. Yao, W. Zeng, and Y. Chen, 1995: Thoroughgoing crustal faults along the northern margin of the South China Sea and their role in crustal extension. J. Geophys. Res., 100, 22435-22446.

Ho, C. S., 1986: A synthesis of the geologic evolution of Taiwan. Tectonophysics, 125, 1-16. 
Ho, C. S., 1988: An introduction to the geology of Taiwan: Explanatory text for the geologic map of Taiwan. Minist. Econ. Aff. Taipei, $2^{\text {nd }}$ ed., $164 \mathrm{pp}$.

Hsieh, S. H. and C. C. Hu, 1972: Gravimetric and magnetic studies of Taiwan. Petro. Geol. Taiwan, 10, 283-321.

Hu, J. C., J. Angelier and S. B. Yu, 1997: An interpretation of the active deformation of southern Taiwan based on numerical simulation and GPS studies. Tectonophysics, 274, 145-169.

Juang, W. S. and J. C. Chen, 1992: Geochronology and geochemistry of Penghu basalt, Taiwan Strait, and their tectonic significance. J. Southeast Asian Earth Sci., 7, 185-193.

Kern, H., 1978: The effect of high temperature and high confining pressure on compressional wave velocities in quartz-bearing and quartz-free igneous and metamorphic rocks. Tectonophysics, 44, 185-203.

King, G., and G. Yielding, 1984: The evolution of a thrust fault system: Processes of rupture initiation, propagation and termination in the $1980 \mathrm{El}$ Asnam (Algeria) earthquake. Geophys. J. R. Astron. Soc., 77, 915-933.

Kinoshita, H., Z. S. Liu, and K. Y. Xia, 1996: Evolution of oceanic crust of the marginal seas in the South China Sea. Univ. Tokyo Press, 59 pp.

Kissling, E., W. L. Ellsworth, D. Eberhart-Phillips, and U. Kradolfer, 1994: Initial reference models in local earthquake tomography. J. Geophys. Res., 99, 19635-19646.

Lallemand, D., Y. Font, H. Bi jwaard, and H. Kao, 2001: New insights on 3-D plates interaction near Taiwan from tomography and tectonic implications. Tectonophysics, 335, 229-253.

Lee, C.-R., and W. T. Chang, 1986: Preliminary heat flow measurements in Taiwan. CircumPacific Energy and Mineral Resources Conf., 4th, Singapore.

Lee, J. C., C. Y. Lu, H. T. Chu, B. Delcaillau, J. Angelier, and B. Deffontaines, 1996: Active deformation and paleostress analysis in the Pakua anticline area of western Taiwan. $T A O, 7,431-446$.

Lin, C. H., Y. H. Yeh, and S. W. Roecker, 1993: Seismic velocity structures in the SanyiFengyuan area, central Taiwan. Proc. Geol. Soc. China, 32, 101-120.

Lin, C. H., 2001: A major earthquake in the strong crust: the 1999 Chi-Chi earthquake. Western Pacific Earth Sciences, 1, 339-350.

Ma, K. F., J. H. Wang, and D. Zhao, 1996: 3-D seismic structure of the crust and uppermost mantle beneath Taiwan. J. Phys. Earth, 44, 85-105.

Macedo, J., and S. Marshak, 1999: The geometry of fold-thrust belt salients. Geol. Soc. Am. Bull, 111, 1808-1822.

Marshak, S., T. Paulsen, and M. Harrison, 2002: Field and modeling constraints on the formation of map-view curves in fold-thrust belts. GSA Annual Meeting, Paper no. 215-3, Denver, Colorado.

Matsumoto, R., 1965: Some molluscan fossils from the buried Cretaceous of western Taiwan. Pet. Geol. Taiwan, 4, 1-24.

Meng, G. Y., 1971: A conception of the evolution of the island of Taiwan and its bearing on the development of the western Neogene sedimentary basin. Petrol. Geol. Taiwan, $\mathbf{9}$, 241-258. 
Mooney, W. D., G. Laske, and T. G. Masters, 1998: CRUST 5.1: A global crustal model at $5^{\circ} \times 5^{\circ}$. J. Geophy. Res., 103, 727-747.

Mouthereau, F., B. Deffontaines, O. Lacombe, and J. Angelier, 2002: Variations along the strike of the Taiwan thrust belt: Basement control on structural style, wedge geometry, and kinematics. Geological Society of America Special Paper, 358, 31-54.

Nissen, S. S., D. E. Hayes, B. Yao, W. Zeng, Y. Chen, and X. Ni, 1995: Gravity, heat flow, and seismic constraints on the processes of crustal extension: Northern margin of the South China Sea. J. Geophys. Res., 100, $22447-22483$.

Ouyed, M., G. Yielding, D. Hatzfield, and C. P. King, 1983: An aftershock study of the El Asnam (Algeria) earthquake of 1980 October 10. Geophys. J. R. Astron. Soc., 73, 605639.

Pavlis, G. L., and J. R. Booker, 1980: The mixed discrete-continuous inverse problem: Application to the simultaneous determination of earthquake hypocenters and velocity structure. J. Geophys. Res., 85, 4801-4810.

Rau, R. J., and F. T. Wu, 1995: Tomographic imaging of lithospheric structures under Taiwan. Earth and Planet. Sci. Let., 133, 517-532.

Roecker, S. W., Y. H. Yeh, and Y. B. Tsai, 1987: Three-dimensional P and S wave velocity structures beneath Taiwan: deep structure beneath an arc-continent collision. J. Geophy. Res., 92, 10547-10570.

Shin, T. C., 1993: The calculation of local magnitude from the simulated Wood-Anderson seismograms of the short-period seismograms in the Taiwan area: TAO, 4, 155-170.

Sleep, N. H., and M. L. Blanpied, 1992: Creep, compaction and the weak rheology of major faults. Nature, 359, 687-692.

Stach, L. W., 1957: Straigraphic subdivision and correlation of the upper Cenozoic sequence in the Foothills region of Chiayi and Hsinying, Taiwan. Symp. Petroleum Geology of Taiwan, Chinese Petroleum Corporation, Taipei, pp. 179-230.

Sun, S. C., 1985: The Cenozoic tectonic evolution of offshore Taiwan. Energy, 10, 421-432.

Suppe, J., 1981: Mechanics of mountain building and metamorphism in Taiwan. Mem. Geol. Soc. China, 4, 67-89.

Suppe, J., 1984: Kinematics of arc-continent collision, flipping of subduction, and back-arc spreading near Taiwan. Mem. Geol. Soc. China, 6, 21-33.

Teng, L., 1990: Geotectonic evolution of late Cenozoic arc-continent collision in Taiwan. Tectonophysics, 183, 57-76.

Thurber, C. H., 1983: Earthquake locations and three-dimensional crustal structure in the Coyote Lake area, central California. J. Geophys. Res., 88, 8226-8236.

Thurber, C. H., 1993: Local earthquake tomography: Velocities and Vp/Vs - Theory, in Seismic Tomography: Theory and Practice, edited by H. M. Iyer and Hirahara, Chapman and Hall, New York, pp. 563-583.

Thurber, C., and D. Eberhart-Phillips, 2000: Local earthquake tomography with flexible gridding. Computer \& Geosciences, 25, 809-818.

Tsai, Y. B., Z.S. Liaw, T. Q. Lee, M. T. Lin, and Y. H. Yeh, 1981: Seismological evidence of an active plate boundary in the eastem Taiwan area. Memoir of the Geological Society of China, 4, 143-154. 
Um, L., and C. H. Thurber, 1987: A fast algorithm for two-point seismic ray tracing. Bull. Seism. Soc. Am., 77, 972-986.

Wang, C., T. H. Huang, I. C. Yen, S. L. Wang, and W. B. Cheng, 2000: Tectonic environment of the 1999 Chi-Chi earthquake in central Taiwan and its aftershock sequence. TAO, 11, 661-678.

Wang, C., C. P. Hwang, L. Y. Ke, S. K. Hsu, C. T. Shyu, W. B. Cheng, and C. S. Lee, 2002: Oblique lithospheric collision and propagation of the Taiwan island as a Solitary wave along the continental shelf edge: magnetic and seismological evidence. TAO , 13, 339354.

Wang, C. Y., and T. C. Shin, 1998: Illustrating 100 years of Taiwan seismicity. TAO, 9, 589614.

Wang, C. Y., C. H. Chang, and H. Y. Yen, 2000: Aninterpretation of the 1999 Chi-Chi earthquake in Taiwan based on the thin-skinned thrust model. TAO, 3, 609-630.

Xia, K., C. Huang, S. Jiang, Y. Zhang, D. Su, S. Xia, and Z. Chen, 1994: Comparison of the tectonic and geophysics of the major structural belts belsurveyed jointly by China and USA. China Univ. Geosciences Press, Wuhan, 204 pp.

Yao, B., 1998: Crust structure of the northern margin of the South China Sea and its tectonic significance. Marine Geology \& Quaternary Geology, 18, 1-16.

Yu, S. B., H. Y. Chen, and L. C. Kuo, 1997: Velocity field of GPS stations in the Taiwan area. Tectonophysics, 274, 41-59.

Zhao, D., A. Hasegawa, and S. Horiuchi, 1992: Tomographic imaging of P and S wave velocity beneath northeastern Japan. J. Geophys. Res., 97, 19909-19928. 